\title{
THE SETTING OF 2 CORINTHIANS
}

By Ralph P. Martin

\section{Introduction}

This lecture will seek to place the letter known as 2 Corinthians in Paul's life as a missionary and church leader whose apostolic standing was a subject of heated debate at Corinth. To achieve our aim we shall need to sketch the course of apostolic history in outline, and indicate, according to one proposed theory, the way Paul's vocation was shaped by the flow of events that led to the composing of the letter. This task is best approached by recounting a series of statements which mark the train of events relating to Paul's role as apostle in the early church, as seen through his letters and the data of Acts, however problematic the data in Acts may appear to be. In this way our endeavour will be to show that the contents and chief emphases of 2 Corinthians are most adequately appreciated by setting the letter in a historical and theological Sitz im Leben in Paul's missionary career. And we will be indirectly challenging C. J. A. Hickling's position in his article 'Is the Second Epistle to the Corinthians a Source of Early Church History?' 1 He responds negatively to his question by seeing the letter as not consisting of a 'locally directed polemic' occasioned by Paul's opponents at Corinth (p. 286). Hickling, to be sure, rightly emphasizes 'the personal factors that emerge strongly in the confrontation' between Paul and the Corinthians. But when he denies the force of 'doctrinal' issues separating Paul and his readers, with the opponents forming a third member of the triangle of relationships, he cuts himself off from a valuable source of information. He thus does not allow the setting of the letter to come to the aid of exegesis. We may concede that Hickling's caution in refusing to get caught in an 'exegetical circle' is praiseworthy. Nonetheless, when he concludes that 'we must remain largely in ignorance of the doctrinal position or tendencies of Paul's rivals... [and that Paul's] magnificent theological

1. ZNW 66 (1975) 284-287. 
assertions are enumerated not principally as polemic but as a positive support for his exposition of the meaning of his apostleship' (p. 287), he is correct in what he affirms but wrong in his unnecessary scepticism and denials. Paul's personal history, we shall maintain, and chiefly his self-understanding as apostle, cannot be separated from the ongoing theological debate with his detractors. His self-identity -- and its theological undergirding -- was sharpened and refined precisely because he was called on to defend it in the face of his opponents' attacks, notably at Corinth.

This is the thesis the paper seeks to offer, and to reach our conclusion we need to rehearse the course of early Christian history as it is germane to Paul's self-designation as apostle.

1. A suitable terminus a quo for our study of Paul's history is the so-called 'famine' visit of Acts 11:27-30. Paul and Barnabas came to Jerusalem from Antioch-on-the-Orontes where they had united to lead a mission church that was Gentile in ethnic composition (Acts $11: 19-21$ ) and that cherished its freedom from Jewish restrictions. ${ }^{2}$ Yet the visit of Acts $11: 29-30$ was intended to forge a link of practical support and concern between the mother church in Jerusalem and the mission areas of Paul's ministry. If this visit may be equated with the events of Gal. 2:1-10, it will follow that a concordat (of Gal. 2:7) was reached by which the 'pillar' apostles ( $\circ i$ $\sigma \tau \tilde{U} \lambda \circ \mathrm{L}$ ) and Paul agreed on spheres of service (cf. 2 Cor. 10:12-18), and he tacitly refused to accept the insinuations of the 'false brothers' who sought to infiltrate the ranks of Gentile congregations in Galatia as agents provocateurs (Gal. 2:4-5). Paul and Barnabas are seen as genuine representatives of the Gentile mission, with credibility in the eyes of the Jerusalem leaders. Yet Antioch, in sending its delegates both in Acts 11 and in Acts 15, was expressing a concern to retain the link with the mother church. ${ }^{3}$

2. J. P. Meier (with R. E. Brown), Antioch and Rome. New Testament Cradles of Catholic Christianity (New York: Paulist, 1983) 32-35.

3. B. Holmberg, Paul and Power. The Structure of Authority in the Primitive Church as Reflected in the Pauline Epistles (Philadelphia: Fortress, 1980) 18-20. 
2. This agreement led to an outbreak of Jewish Christian opposition to the Pauline mission, with the centre of the controversy the question of circumcision. This issue had already provoked much discussion on a broader front. The place of circumcision and whether it was required to be practised on Gentile inquirers as a sine qua non of entry into the Jewish community were spotlighted in the case of Izates of Adiabene who initially wished to identify himself with the Jews but not to the point of accepting the rite of circumcision (see Josephus, Ant. 20.38-48). The concession was evidently made that he could 'worship God without being circumcised, if indeed he had fully decided to be a devoted adherent of Judaism; for it was this that counted more than circumcision'. As it happened, Eleazar of Galilee persuaded him otherwise, and he was circumcised privately. ${ }^{4}$ In turn, there were political pressures exerted on Jewish Christians at a time when the Zealot movement in Judea aimed to force Jews to close ranks against paganizing influences. 5 The Jewish believers in Jesus would be caught in a double-bind: on the one hand, they were anxious to honour their patriotism by declaring themselves to be loyal to the ancestral faith and its tradition; on the other side, they could see how Paul's reported actions (later to be garbled, according to the witness of Acts 21:18-25) would -- if left unchecked -- offer a frontal assault on the Jewish religion, and subsequently lead to the church's becoming exclusively Gentile and so cut off from its Jewish roots. The author of Acts hardly gives this case a full hearing, and views it only as a threat to the Pauline message and mission praxis that rests on the free, untrammelled grace of God apart from ritual or cultic observance. So the protestation of the Jewish Christians is given in stark terms in Acts 15:1: 'Some men came down from Judaea [to Antioch?] and were teaching the brothers: "Unless you are circumcised according to the custom taught by Moses, you cannot be saved."' This sentiment, in all its frankness, needs to be read in the light of Acts 15:11 where Peter's

4. F. F. Bruce, New Testament History (London: Nelson, 1969) 266.

5. B. Reicke, The New Testament Era (London: Black, 1969) 202-203; R. Jewett, 'The Agitators and the Galatian Congregation,' NTS 17 (1970-71) 198-212 for the evidence in Josephus, Ant. 20.102, 168-169. 
response is couched in language replete with Paul's theological idiom and missionary topicality: 'We believe it is through the grace of our Lord Jesus Christ that we (Jewish Christians) are saved, just as they (i.e. Gentile believers) are.'

Paul and Barnabas were, therefore, delegated by the Antiochenes to go to Jerusalem to confer with the Jewish Christian leaders. This, in our view, is the background to the so-called council of Jerusalem, c. A.D. 50 or 51 .

3. At the conference, reported in Acts 15:1-21, a three-cornered discussion got underway, though we have only minimal information and several questions were unresolved. The central issue that provoked the meeting in the first instance (Acts 15:5) was that of the rite of circumcision which, it was insisted from the Jewish Christian side, must be imposed on Gentile converts to the messianic faith. Peter led off as the first contributor to the debate. He stood in the role of 'bridge-man', 6 ostensibly spanning the gap between the different factions, and providing a link to unite Jewish and Gentile susceptibilities on the basis of his own experience after the Cornelius episode (Acts 10, 11) and in concurrence with the arrangement already made in Galatians $2: 4,7$.

Paul is the second voice to be heard (Acts 15:12) as he summarily reported the success that had followed the initial evangelism he conducted in Syria, Cilicia and Antioch (cf. Gal. 1:21). Then, it was James, the Lord's brother, who proposed a modus vivendi from the Jewish Christian side, which was evidently aimed at quieting the apprehensions of that group. The 'decree' (v. 20), however, neatly circumvents the question of circumcision, and instead concentrates on a less heated topic, namely table fellowship between Jewish and nonJewish parties and the requirements to be met if such cordiality was to be continued. The Gentiles are left

6. To use J. D. G. Dunn's term, Unity and Diversity in the New Testament (Iondon: SCM, 1977) 385; see too M. Hengel, Acts and the History of Earliest Christianity (London: SCM, 1979) 92-98. 
in no doubt that they are under obligation (derived from the Noachian laws of Judaism that were believed to be God's original intention to unite all people in accepting a basic moralistic and dietary code, derived from Gen. 9:4) ${ }^{7}$ to abstain from the items as listed. Paul -- and perhaps Peter -- may not have been present at this phase of the conference, since in Acts $21: 18-25$ James announces the decree as something evidently new to Paul (v. 25, 'we have written' seems to exclude Paul)..$^{8}$

4. The situation, following the council, developed in a way which caused alarm among the more zealous Jewish Christians. We may postulate the reasons for their consternation. Paul's mission preaching in Acts 13, 14 opened the door to the evangelization of Gentiles en masse. In that preaching no mention was made of circumcision, as indeed the matter had been glossed over at the Jerusalem meeting. According to Acts 14:23 Paul quickly followed up his initial evangelism by proposing a rudimentary church organization involving a Jewish structure, namely the appointing of 'elders' to oversee the nascent communities. The Jewish believers responded to what occasioned their fear by nominating Judas and Silas to enforce the decree at Antioch. Paul's presence at Antioch is clearly certified in the text (Acts 15:35), but it is a moot point whether he and Barnabas should be associated with the decree in this chapter or at Acts 16:4. It seems clear that Luke's purpose is to highlight the harmony between various factions and their leaders. It is noteworthy that at Corinth where matters germane to the items of the decree were warmly debated, especially $\varepsilon i \delta \omega \lambda o ́ v u \tau \alpha$, 'food offered to idols' (1 Cor. $8: 1-9), 9$ he never once appeals to that authority.

7. G. F. Moore, Judaism in the First Three Centuries of the Christian Era (Cambridge, Massachusetts:

Harvard, 1927-30) 1. 274-275, 339.

8. So Hengel, Acts 117: 'There James presents it [the decree] as something new and apparently unknown to him.'

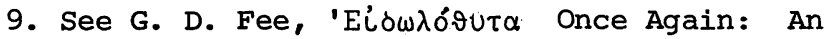
Interpretation of 1 Corinthians 8-10,' Biblica 61 (1980) 172-197. 
Instead, in 1 Corinthians Paul's court of appeal is much more personal than to any document, even if it may have emanated from an august source, the Jerusalem hierarchy. He appeals to what F. Büchsel calls 'the obligation of love' (Liebespflicht). 10

Peter's behaviour at Antioch, according to Galatians 2:12, was the cause of further Jewish Christian concern. The emissaries from James attacked his practice of consorting with Gentiles: the issue was apparently not that of table fellowship per se, as in Galatians 2:12, but the easy-going attitude that led peter to sit down with uncircumcised people. Hence Paul writes later in that verse: 'he was afraid of those who belonged to the circumcision group' (NIV, italics added).

5. The record of the confrontation between Paul and Peter at Antioch (Gal. 2:11-14) poses its own set of problems to the modern interpreter. ${ }^{12}$ The modern consensus is that Paul 'lost' his case at Antioch, and thus his alienation from Antioch began at this point. 12 The issue under dispute was the question of whether new Christians should 'live as Jews' (2:14) by following

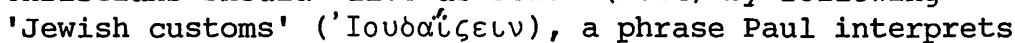
to mean both the acceptance of the kosher laws in regard to food and the practice of circumcision. Peter vacillated at these points where the Jewish Christians were insistent (reinterpreting the decree, it may be, in their own interests to include circumcision) ${ }^{13}$-- and on

10. TDNT 2.379.

11. See Holmberg, Paul and Power 32-34; J. D. G. Dunn, 'The Incident at Antioch,' JSNT 18 (1983) 3-57, with Responses by J. L. Houlden (58-67) and D. CohnSherbok (68-74); P. Stuhlmacher, 'Das paulinische Evangelium' in Das Evangelium und die Evangelien, ed. P. Stuhlmacher (Tübingen: Mohr, 1983) 175-178.

12. Holmberg, Paul and Power 34 n. 117; Hengel, Acts 119-123.

13. Dunn's remark to the effect that the 'Jerusalem Council' settled only the circumcision issue and that the so-called 'apostolic decree' stipulating the limits of table-fellowship reflects a later agreement seems to me to be the exact opposite of how it was (Dunn, 'Antioch' 38). Acts 15:12-29 says nothing about circumcision, whereas the insistence on the rite in Galatia became very much the hot issue. 
his side, Paul was emphatic, since he interpreted the council's meeting in his own way. ${ }^{4}$ He regarded Peter's tame acceptance of Jewish Christian pressure as intolerable; it was nothing short of a move away from 'the truth of the Gospel' (Gal. 2:5) agreed upon in the working arrangement of the earlier concordat. At this point, as D. R. Catchpole ${ }^{15}$ guggests, Paul hardened his attitude to the decree. It was seen not as a gesture of conciliation leading to unity, but as a step backward and a capitulation to the Urgemeinde, the primitive Jerusalem church, with its limitation on mission. Up to this juncture and turn of events, Paul may well have tolerated the value of the decree, possibly because it was concerned in its first drafting with matters such as a detestation of idolatry and immorality, and an adoption of food rules which Paul took to be axiomatic for his converts or at least as a matter of indifference (1 Cor. 6:18-20; 8:4-8: 'food does not bring us near to God'). It may be that he did not treat these issues as central to the kerygma (Rom. 14:14-18) or that his attitude is explained by his flexibility. As F. F. Bruce 16 puts it: 'Where the principles of the gospel were not at stake he was the most conciliatory of men.' More likely still, we may see in Paul's later resistance to and passing over of the decree the final development of his repugnance from the beginning. Again Catchpole is surely correct in detecting three aspects of the decree that would have made the formula distasteful to him: its Mosaic character, its implicit separation of Jew and Gentile on ethnic grounds, and its observance of a levitical code based on ceremonial cleanness. The Paul who wrote 2 Corinthians 3:1-18; Galatians 3:28; and Romans 3:27-31 is hardly likely to have been enthusiastic at a formulation of Christianity that served only to accentuate both the Jewishness and the exclusiveness of

14. Holmberg, Paul and Power 21-23.

15. 'Paul, James and the Apostolic Decree,' NTS 23 (1977) 428-444.

16. Paul, Apostle of the Free Spirit (Exeter: Paternoster, 1977) 186; cf. C. Rowland, Christian origins (London: SPCK, 1985) 232-235. 
that faith on ritualistic grounds. So Paul was driven to conclude that the decree was an attempt to put the clock back and to turn the course of the Christian mission into antiquated channels.

\section{II}

Such a momentous conclusion, however, had farranging repercussions for Paul in his missionary vocation that were based on theological convictions, not pragmatic grounds. We may list the consequences of his apparent 'defeat' following the confrontation at Antioch.

(1) It sharpened the focus of his gospel to a point where justification apart from the works of the law became a pivotal issue, and the results of this narrowed focus are seen in the polemical statements in Galatians and Philippians, with a more measured exposition in the letter to the Romans -- at least up to Chapter 4. 'Justification by faith' became, under the exigencies of this flow of events, a clarion call of the Pauline mission since it served to show the distinctiveness of Paul's missionary theology vis-ä-vis the Jewish Christians' counterclaim. Whether 'justification' had a larger purpose as providing a groundwork for Paul's theology at its centre may be doubted; and we have sought to argue that a more comprehensive term such as 'reconciliation' takes over as representing the quintessence of Paul's message to the Gentiles adumbrated in 2 Corinthians 5:18-21 and fully fashioned in Romans once the debate with the Jewish Christians receded from view. 17

(2) Paul's stance set him in inevitable opposition to the 'pillar' apostles, whose authority he now proceeded to challenge, partly in pursuance of his loyalty to 'the truth of the gospel' which he felt they had betrayed and partly in response to the insinuation that began to appear from this quarter of Jewish Christianity that he was in fact no true apostle -indeed, that he was no apostle at all (note the correct translation of 2 Cor. 12:11b, obscured in the RSV), or

17. R. P. Martin, Reconciliation: A Study of Paul's Theology (London: Marshall, Morgan and Scott, 1981) 149-154; cf. J. W. Drane, Paul. Libertine or Legalist? (London: SPCK, 1975) ch. 3. 
even, if E. Käsemann ${ }^{18}$ is correct on the basis of 2 Corinthians 10:7, that he was not a Christian person. This innuendo is clearly in his sights at the time of the Corinthian crisis, and sets the agenda of his writing of 2 Corinthians chapters 3-7, 10-13, chapters which in different ways resist the insinuation that he has no apostolic status. Moreover, they demonstrate what he regarded as his valid credentials over against the opponents who attempted to base their apostolate on the figure of Moses, and to appeal to the self-styled 'super-apostles' ( 2 Cor. 11:5; 12:11, NIV) as authorities to justify their status as 'servants of Christ' (2 Cor. 11:23) and 'apostles of Christ' (2 Cor. 11:13).

(3) Paul's isolation from Jerusalem was a somewhat ambivalent feature of this stage of his life. He still professed a concern for national Israel, Israel

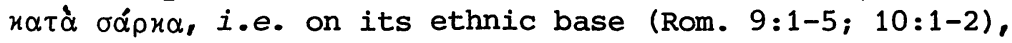
and he still was willing to reach out in compassion and in practical ways to aid the 'poor saints' in the holy city (2 Cor. 8-9; Rom. 15:25-31; cf. Gal. 2:10). Nonetheless, the evidence of a break with his former colleagues is only too apparent: he separated from his original sponsor Barnabas (Acts 9:26-28; 15:36-41), and he found a congenial partner in Silas, shifting his power base from Antioch to Asia. Indeed, we may see how Antioch as a church centre increasingly moved in the direction of a rapprochement with Jewish Christianity in its acceptance of the primacy of Peter according to Matthew's Gospe1 (Mt. 14:28-29; 16:16ff.; 17:24; 18-21), 19 its desire to keep open some lines of communication with the ancestral faith in spite of persecution, and its openness to Christian nomism and particularism as safeguards against too radical a version of the Pauline gospel (e.g. Mt. 5:17-20; 7:21; $10: 5-6 ; 15: 24$; $19: 28$; $23: 2-3,23$ ).

18. Die Legitimität des Apostel Paulus. Eine Untersuchung zu II Korinther 10-13 (Darmstadt: Wissenschaftliche Buchgesellschaft, 1956) 11, 12.

19. Brown and Meier, Antioch and Rome 45-72; Hengel, Acts 98. 
Paul's chief centres of ministry are now located in the Roman world: at Philippi where his mission church-building is hailed as 'the beginning of the gospel' (Phil. 4:15), ${ }^{20}$ at Corinth, and at Ephesus. In these church communities Paul worked out the logic of his chosen position. He proclaimed and applied a universal, law-free, circumcision-less gospel, detached from ceremonial restrictions and cultic taboos which, once they were reintroduced either from the Jewish (as in Philippians) or hellenistic side (as in Colossians), had to be resisted in the name of Paul's teaching of sola gratia, sola fide.

In 2 Corinthians 10:12-18 Paul handles a theme of some complexity. The writing is tortuous, evoking such judgments as 'notably clumsy', containing 'oddly confused expressions', 'intolerable constructions' (Windisch, 312, 313), and full of 'chopped up pieces of sentences, violently thrown together' (Lietzmann, 143, with some exaggeration, surely). Yet the general drift is reasonably clear. Paul wants to justify his mission to Corinth on the ground that he is working within the

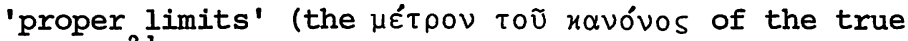
apostle $\mathrm{e}^{2 \mathrm{l}}$ ) God has assigned him. He has no intention of

20. See J. Gnilka, Der Philipperbrief (Frieburg i.B.: Herder, 1968) 177.

21. So Käsemann, Legitimität 43-51. The terms $\mu \varepsilon ́ \tau \rho o \nu$ and $x \alpha \nu \omega ́ v$ are difficult to translate in this context, where they are evidently being used in a semi-technical way. The notion of measurement lies at the heart of the issue and, in particular, the geographical area assigned to apostolic leaders in the early church (cf. Gal. 2:7-9), the territorial 'assessment' or perhaps 'ministry' (1 Clem. 1:3; $41: 1)$ by which God has measured out their territorial commitments (so E. A. Judge, New Documents [1976], ed. G. H. R. Horsley, North Ryde: Macquarie Univ., 1981,45 ; cf. New Documents [1977] ed. G. H. R. Horsley, North Ryde: Macquarie Univ., 1982, no. 55). 
going 'beyond the proper limits' (10:15) to trespass on the turf which rightly belongs to 'others', presumably Jewish Christian leaders whose derogatory attitude to Paul's mission at Corinth lies in the background. He has been accused of having no right to be at Corinth where Peter and Barnabas were evidently well known and received (1 Cor. 9:5-6).22 This paragraph is one of the most forthright statements, along with Romans 15:17-22, of Paul's self-defensive response to those who alleged that he was an interloper. With fervency and boldness he retorted that his apostolic writ did run in those Gentile areas which God had given him -- and which the 'pillar' men had earlier accepted (Gal. 2:7-9) -- as his bailiwick. 23

The point of this discussion is that, with Paul's disaffection in regard to Antioch as a base of missionary operations, he was temporarily without spiritual Heimat and vulnerable, since he could be regarded as an itinerant preacher doing very much solo work and without a legitimating 'home' base. The 'letters of recommendation' (3:1-3) carried to Corinth by Paul's competitors have to be seen in this light. 'Thus they always represented some specific Christian community. Paul did not. ${ }^{24}$ Hence he articulates his insistence that at Corinth he is doing the Lord's work among people to whom he has been sent (1 Cor. 1:1; $15: 58^{25}$, and has his credentials in human lives

(2 Cor. 3:1-3; cf. 1 Cor. 9:1, 2).

(4) So we reach, by this circuitous route, the occasion of 2 Corinthians and its Sitz im Leben in Paul's missionary career. Not the least consequence of the train of events which led to his stand against

22. C. K. Barrett, 'Cephas and Corinth', Essays on Paul' (London: SPCK, 1982) chap. 2.

23. C. K. Barrett, 'Paul and the "Pillar" Apostles', in Studia Paulina in honorem Johannis de Zwaan (Haarlem: Bohn, 1953) 1-19.

24. G. Theissen, The Social Setting of Pauline Christianity. Essays on Corinth (Edinburgh: T. \& T. Clark/Philadelphia: Fortress, 1982) 50.

25. Holmberg, Paul and Power 30, 31 et passim. 
Jewish Christians and especially his confrontation with the emissaries he opposes in 2 Corinthians 10-13 was a new expression of his confidence in his own apostleship.

The emphasis on Paul's 'rightful apostolate' has been regarded by $B$. Holmberg ${ }^{26}$ as occasioned by the presence of rival apostles at Corinth and their initial success in ousting him from his position of authority in that community. So we may conclude that it was this new factor (seen in 11:4 where ó Épxóuevos, 'he who comes', implies a visit of emissaries hitherto unknown, armed with a rival gospel) which led to Paul's stance. 'What Paul threatens to do in 2 Cor. 10:1-6 and 13:10 is thus something he has never before attempted in Corinth' (Holmberg, 77), namely to engage in fierce polemic and exert his God-given right ( $\varepsilon^{\prime} \xi \cup \cup \ell^{\prime} \alpha$ ) as a 'divine apostle'. The issue in this discussion turns on Paul's consciousness of being such an apostle, possessing a legitimate apostolate.

But what is noteworthy is that it was reformulated in a surprisingly novel manner. The pressure of these events which set him apart from Jewish Christian leaders and those who claimed their authority in Corinth and brought him under a cloud of suspicion made it inevitable that he would define his role as a suffering apostle whose authority is seen in his frailty and inherent weakness ( 2 Cor. $4: 7-12 ; 12: 9-10 ; 13: 3,4,9$ ). Paul's credentials are not found in written documents but in the lives of his people (2 Cor. 3:1-3). More particularly he appeals to the inner reality rather than the tangible and evidential $(4: 16-18 ; 5: 12 ; 13: 3)$. This self-evaluation is a natural corollary of Paul's new insights into soteriology, or the way God saves believers. The cross, for Paul, took on a new dimension as the place of divine humiliation and self-giving, expressed in Christ's surrender of all he had or could be (2 Cor. 8:9; Phil. 2:6-11).

26. Holmberg, Paul and Power 77. 
III

With some justification we may trace to this time in his life a clear articulation of a theologia crucis in contradistinction to both a theologia gloriae ('theology of glory') which was prevalent at Corinth among a hellenistic group there and a nomistic bid to bracket the cross with an insistence on circumcision as equally necessary to salvation. 'If righteousness could be gained through the law, Christ died for nothing' (Gal. 2:21, NIV) is one of his most trenchant denials of the latter proposal.

The genesis of Paul's teaching on Christ's cross as the locus of divine power-in-weakness (1 Cor. 1:18-2:5) and of his own ministry as 'weak in him' may go far to explain the statistical phenomena addressed by D. A. Black's recent study. 27 He shows -- but does not ask why the evidence leads to the conclusion -- that Paul's term for 'weakness' ( $\alpha \sigma \vartheta \varepsilon \dot{v} \varepsilon(\alpha)$ is most frequent in the Corinthian letters (29 examples out of a total of 44 uses; in 2 Corinthians the ratio is 14 instances out of 44; these 14 examples are all in 2 Cor. 10-13). 'In these two letters (and to a lesser degree in Romans) he develops weakness into a theological formulation.'28 This is true. The question now is posed: What led Paul to make this formulation? It can hardly have been only 'the loneliness and discouragement of his disappointing visit to Athens (Acts 17)', as Black surmises (p. 101). A deeper cause is suggested, and we propose that it lay in the coherence of his own experience of isolation from earlier missionary support, the nature of the Corinthian crisis which struck a blow at his apostolic authority, and his need to redefine the gospel in terms of a clear distinction from Judaism and Jewish Christian ideology. In consequence, he came to express the message as 'the word of the cross' ( 1 Cor. $1: 18$ ), and God's power was traced to the hidden wisdom of Christ's weakness by which the mighty were overcome

27. Paul, Apostle of Weakness. Astheneia and its Cognates in the Pauline Literature (New York: Lang, 1984).

28. Ibid. 85 (his italics). 
(1 Cor. 1:27-29; 2 Cor. 10:3-5; by contrast see 11:30-33). 'Crucified in weakness' (2 Cor. 13:4), Christ achieved salvation by surrendering his glory, by self-giving in taking the slave's condition, and by obedience to death. Paul's language coheres precisely with this new insight born out of the experiences that came to him at this crucial time in his life and career. 29

W. C. Robinson's allusion to 'the use of preformed material in a concrete situation' ${ }^{30}$ may be illustrated by an appeal to Philippians 2:6-11, the Christ-hymn that celebrates the odyssey of the redeemer from eternity to his final glory as ruler of all. This carmen Christi has been intensively studied, and we may pick out from the complexities of recent discussion several items that bear upon the experience of Paul at the time of his writing 2 corinthians. We may take as a working hypothesis the dating of Philippians in Paul's Ephesian ministry, i.e. at the same time as the Corinthian crisis was filling his mind. Granted, in the Philippian letter, Paul uses a traditional piece of hymnic material; but its setting is clearly paraenetic, leading to the hortatory appeal of 2:12, which in turn has the pastoral situation of $2: 1-4$ in its sights.

One way that Paul has utilized the preformed hymn is to pick up the theme of 'obedience' in his applicatio at $2: 12$. By common consent Philippians 2:6-8 is centred on the obedience of the one who entered our human lifestream at great cost and consented to accept a life of humiliation and self-denial of his rights, as

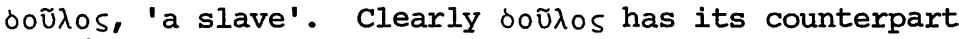
in $x$ úplos, 'Lord', which is the title now bestowed on

29. J. H. Schütz, Paul and the Anatomy of Apostolic Authority (Cambridge: CUP, 1975) 235-248; W. C. Robinson, Jr. 'Word and Power (1 Corinthians 1:17-2:5)' in Soli Deo Gloria. New Testament Studies in Honor of William Childs Robinson, ed. J. M. Richards (Richmond: John Knox, 1968) 68-82.

30. Robinson, 'Word and Power' 79. 
the exalted Christ (v. 11). But the inclusion of the earthly name 'Jesus' in the ascription of praise at $v .11$ is meant to point back to the first part of the hymn and to cast its shadow across his earthly existence which is traced in a course of several actions that are denoted by stark reflexive verbs but with no explicit subject in vv. 6-8. All we know, from the original draft of the hymn, is that a heavenly being ( $v .6)$ who existed as the divine image consented to embark on a life of selfabnegation. The inclusion of 'Inoous in the acclamation formula of $\mathrm{v} .11$ is designed to hark back to that earthly life, which is no charade or mock example as though the heavenly one was simply going through the motions as a piece of histrionics. He was really involved -- since his name, now revealed at the enthronement, is 'Jesus' which is attached to the title of exaltation, 'Lord'.

This is precisely Paul's point at 1 Corinthians 12:1-3 (according to one interpretation ${ }^{31}$ of an

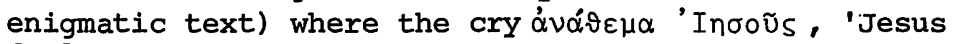
[be] damned' -- surely as offensive to Paul as to the present-day Christian believer -- was heard at Corinth as some members were disclaiming interest in the earthly Jesus in favour of concentrating their religious aspirations on the heavenly aeon, Christ. Their enthusiastic reaching out to Christ as world ruler and Lord of the congregation is coolly received by Paul whose gospel insists on holding together the earthly Jesus with the exalted Lord if that gospel is not to evaporate into a 'docetic' philosophy or a species of gnostic religiosity akin to prevalent hellenistic cult devotion. Paul's antidote is to be seen in 2 Corinthians 4:9-12 where the frequent allusion to the name 'Jesus' is not an accident, but serves to enforce his major thrust against his opponents.

Also, it seems fairly certain that Paul in taking over this 'hymn to Christ' has redacted it -- by the

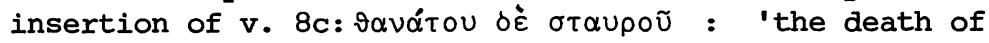
the cross' -- to enforce its appeal, and to anchor the incarnational motifs of vv. 6-8 in the saving event which involved the redeemer's death on a cross. The

31. w. Schmithals, Gnosticism in Corinth (Nashville: Abingdon, 1971) 124-132. He links the mention of

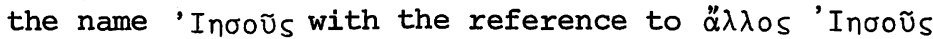
in 2 cor. 11:4 -- another crux criticorum (Gnosticism 132-135). 
function of that coda (in v. 8c), along with the elements of his earthly humiliation and obedience, reveal to the Philippians that it is the crucified Jesus whom they acknowledge as Lord (v. 11). Their life 'in Christ Jesus' (v. 5) is to be governed by that control, and the reminder -- based on a theologia crucis -- is Paul's way of summoning his readers to face the outworking of what the Christian life is all about. ${ }^{32}$

This setting of the cross at the heart of the hymn, as it is moulded under Paul's design, shows where the paraenetic appeal lies: it assists in giving a kerygmatic dimension to the readers' life in Christ by anchoring what they understand as life under Christ's lordly control (a conviction shared by Paul and his readers) in a 'theology of the cross'. The cross, in the understanding Paul has learned at this phase of his mission, is not a station on the road to glory or a temporary diversion quickly to be passed over in a retelling of the story of Christ. ${ }^{3 \frac{3}{3}}$ Rather the cross is of the esse of Christian existence, and the decisive criterion of what Paul calls in 2 Corinthians

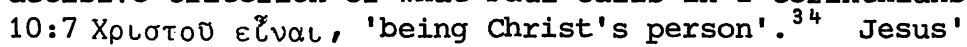
death is rightly seen not as a mere fact of past history or an episode that was soon to be swallowed up in the glory of the risen one. It is the hallmark of all that characterized Jesus' historical person and saving significance, and to proclaim him is to proclaim the cross (1 Cor. $1: 18 ; 2$ Cor. $4: 1-6 ; 5: 1-21$ ). To treat the cross in any other way -- as in the case of those to whom Paul writes 2 Corinthians 5:11-21 -- is to subvert its meaning. Worse, it is to range oneself with those (as in 2 Cor. 6:14-7:1, 11:13-15) who are elsewhere called 'the enemies of Christ's cross' (Phil. 3:18; cf. 2 Cor. 2:15-17).

32. We may refer to our Carmen Christi (Grand Rapids: Eerdmans, $1983^{2}$ ) xii-xxxix.

33. As the church to which 1 Cor. 15 was written was imagining: see R. P. Martin, The Spirit and the Congregation (Exeter: Paternoster, 1984) ch. 6 .

34. Käsemann, Legitimität 11. 
The obverse side of this teaching is the practical application of the kerygma of the cross to the apostolic ministry. Now it is seen -- for the first time by any Christian leader in early Christianity of whom we have record -- that the esse of the church is its role as a suffering people, and that the title to service is written in Paul's own self-designation as 'dying with Christ' (2 Cor. 4:10-11; 5:14-15; 13:4). Rightly, therefore, does $R$. C. Tannehill ${ }^{35}$ remark: 'The past dying with Christ and the present dying with Christ in suffering are not two unrelated things, but the same thing taking place on two different levels.' Yet that place of weakness is also paradoxically the seat of apostolic authority ( $\varepsilon \xi o v \sigma i ́ a, 2$ Cor. 10:8, 13:10) -but it is power harnessed to the service of love in seeking to build up, not pull down, and enlisted to encourage people to grow in the maturity of faith (2 Cor. $1: 24)$.

In this sketchy review we see the sequence of historical happenings that brought Paul to a lonely place. When viewed in a theological frame of reference and seen sub specie aeternitatis the events that led him to face the Corinthian crisis produced, in the alchemy of divine overruling, a magnificent exposition of what the Christian life is all about, how the church of Christ should see its existence and mission in the world, and the ways that Christian service in a true apostolic succession should be spelt out in his and all generations.

In summary I believe that the question posed in Hickling's title -- 'Is the Second Epistle to the Corinthians a Source of Early Christian History?' -should be answered in the affirmative.

35. Dying and Rising with Christ (Berlin: Töpelmann, 1967) 177. 